\title{
Comment on: "Using Field Based Data to Model Sprint Track Cycling Performance"
}

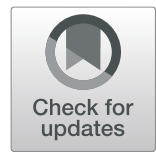

Jamie Douglas ${ }^{1,2}$

Dear Editor,

I commend Ferguson et al. [1] on elucidating the challenges faced by practitioners in optimising sprint cycling performance in their recent narrative review. Upon seeing the title, I was excited to read about field-based data and modelling of sprint cycling. However, I was surprised that the 'data' included only two power metre traces and that the authors performed no modelling. Furthermore, their recommendations were not supported by peer reviewed studies or anecdotal evidence.

They argue that peak power output (PPO) does not differentiate sprint race outcomes, contribute to power production over 15-60s and should not be an objective of training. This position is challenging to understand as perhaps the only study to have investigated the role of PPO per se in elite sprint cycling demonstrated a strong association between PPO (normalised to rider drag area) and flying $200 \mathrm{~m}$ velocity [2], which in turn largely predicts success in sprinting [3]. Furthermore, PPO has been demonstrated to explain $\sim 74 \%$ of the variance in average power during a 30s Wingate test in trained athletes [4]. The authors argue that because a "substantial" proportion of adenosine triphosphate (ATP) regeneration is achieved via the oxidative pathway during efforts of 30-60s, sprint cyclists should instead prioritise 'mixed power/endurance models' of training. Whilst oxidative metabolism contributes $12-45 \%$ of energy resynthesis during efforts of 15-60s [5], metabolic energy release rates during sprint efforts of $\leq 60$ s are limited by mechanical demand and not rates of energy supply per se [6]. Therefore, maximal neuromuscular power (i.e. PPO) and the attenuation of fatigue-related impairments in contractile function (i.e. buffering) remain most critical to

\footnotetext{
This comment refers to the article available at https://doi.org/10.1186/ s40798-021-00310-0.

Correspondence: jamie.douglas@hpsnz.org.nz

${ }^{1}$ High Performance Sport New Zealand (HPSNZ), Avantidrome, 15 Hanlin

Road, Cambridge 3283, New Zealand

${ }^{2}$ Cycling New Zealand, Cambridge, New Zealand
}

sustained maximal 15-60s power production during sprint cycling.

In an attempt to further downplay the importance of $\mathrm{PPO}$, the authors present power-time/distance data from a 16-year-old female to suggest that sprint cycling is not an 'all-out' activity. However, deviations from an idiosyncratic power-duration relationship are typically observed during maximal sprint cycling due to fluctuations in resistance [7], variable pedalling rates [8] and the transition from standing to seated cycling (i.e. two distinct power-duration relationships [9]). These data likely represent 'all-out' effort following the initiation of the sprint (i.e. an optimal power-supply strategy for sprint cycling [10]).

Finally, whilst the sport of sprint cycling does involve multiple sprints, those usually occur with rest intervals of 40-120 min or longer [11]. In contrast, repeated sprint exercise (RSE) is defined as maximal efforts of $\leq 10 \mathrm{~s}$ interspersed with recovery periods of $\leq 60 \mathrm{~s}$ [12]. Consequently, findings on RSE are not applicable to the sport of sprint cycling. Indeed, evidence from elite BMX and Track Sprint athletes suggests no performance impairment across multiple bouts of simulated or actual competition [11,13]. Thus, concerns about recovery between rounds raised by Ferguson et al. are not supported by previous literature.

In summary, oxidative metabolism contributes to sprint cycling performance and should be addressed with training, but not at the expense of PPO or maximal 1560 s power production. The recommendations provided in this narrative review are not evidence-based but represent unsubstantiated opinion and a selective interpretation of the literature.

\footnotetext{
Abbreviations

ATP: Adenosine triphosphate; PPO: Peak power output; RSE: Repeated sprint exercise
}

Springer Open (c) The Author(s). 2021 Open Access This article is licensed under a Creative Commons Attribution 4.0 International License which permits use, sharing, adaptation, distribution and reproduction in any medium or format, as long as you give appropriate credit to the original author(s) and the source, provide a link to the Creative Commons licence, and indicate if changes were made. The images or other third party material in this article are included in the article's Creative Commons licence, unless indicated otherwise in a credit line to the material. If material is not included in the article's Creative Commons licence and your intended use is not permitted by statutory regulation or exceeds the permitted use, you will need to obtain permission directly from the copyright holder. To view a copy of this licence, visit http://creativecommons.org/licenses/by/4.0/. 


\section{Acknowledgements}

The author would like to thank Associate Professor James C Martin for his constructive comments in the preparation of this letter.

\section{Author's Contributions}

The author read and approved the final manuscript.

\section{Funding}

No sources of funding were used to assist in the preparation of this letter.

\section{Availability of Data and Materials \\ NA}

\section{Declarations}

\section{Ethics Approval and Consent to Participate}

NA

\section{Consent for Publication}

NA

\section{Competing Interests}

The author, Jamie Douglas, declares he has no conflicts of interest relevant to the content of this letter.

Received: 29 March 2021 Accepted: 20 July 2021

Published online: 23 August 2021

\section{References}

1. Ferguson HA, Harnish C, Chase JG. Using field based data to model sprint track cycling performance. Sports Med Open. 2021;7(20):1-12.

2. Dorel S, Hautier CA, Rambaud O, Rouffet D, Van Praagh E, Lacour JR, et al. Torque and power-velocity relationships in cycling: relevance to track sprint performance in world-class cyclists. Int J Sports Med. 2005;26(9):739-46. https://doi.org/10.1055/s-2004-830493.

3. Phillips KE, Hopkins WG. Factors affecting cyclists' chances of success in match-sprint tournaments. Int J Sports Physiol Perf. 2019;14(4):472-7. https://doi.org/10.1123/ijspp.2018-0346.

4. Inbar $O$, Kaiser $P$, Tesch P. Relationships between leg muscle fiber type distribution and leg exercise performance. Int J Sports Med. 1981;2(03):1549. https://doi.org/10.1055/s-2008-1034603.

5. Gastin PB. Energy system interaction and relative contribution during maximal exercise. Sports Med. 2001;31(10):725-41. https://doi.org/10.2165/ 00007256-200131100-00003.

6. Bundle MW, Weyand PG. Sprint exercise performance: does metabolic power matter? Exerc Sport Sci Rev. 2012;40(3):174-82. https://doi.org/10.1 097/JES.0b013e318258e1c1.

7. Martin JC, Gardner AS, Barras M, Martin DT. Modeling sprint cycling using field-derived parameters and forward integration. Med Sci Sports Exerc. 2006;38(3):592-7. https://doi.org/10.1249/01.mss.0000193560.34022.04.

8. Gardner AS, Martin DT, Jenkins DG, Dyer I, Van Eiden J, Barras M, et al. Velocity-specific fatigue: quantifying fatigue during variable velocity cycling. Med Sci Sports Exerc. 2009;41(4):904-11. https://doi.org/10.1249/MSS.0b013 e318190c2cc.

9. Reiser RF, Maines JM, Eisenmann JC, Wilkinson JG. Standing and seated Wingate protocols in human cycling. A comparison of standard parameters. Eur J Appl Physiol. 2002;88(1-2):152-7. https://doi.org/10.1007/s00421-0020694-1.

10. van Ingen Schenau GJ, De Koning JJ, de Groot G. Optimisation of sprinting performance in running, cycling and speed skating. Sports Med. 1994;17(4): 259-75. https://doi.org/10.2165/00007256-199417040-00006.

11. Klich S, Krymski I, Kawczynski A. Viscoelastic properties of lower extremity muscles after elite track cycling sprint events: a case report. Centr Eur J Sport Sci Med. 2020;29(1):5-10

12. Girard O, Mendez-Villanueva A, Bishop D. Repeated-sprint ability - part I: factors contributing to fatigue. Sports Med. 2011;41(8):673-94. https://doi. org/10.2165/11590550-000000000-00000.

13. Louis J, Billaut F, Bernad T, Vettoretti F, Hausswirth C, Brisswalter J. Physiological demands of a simulated BMX competition. Int J Sports Med. 2013;34(6):491-6. https://doi.org/10.1055/s-0032-1327657.

\section{Publisher's Note}

Springer Nature remains neutral with regard to jurisdictional claims in published maps and institutional affiliations.

\section{Submit your manuscript to a SpringerOpen ${ }^{\circ}$ journal and benefit from:}

- Convenient online submission

- Rigorous peer review

- Open access: articles freely available online

High visibility within the field

- Retaining the copyright to your article

Submit your next manuscript at $\boldsymbol{\nabla}$ springeropen.com 